\title{
Life Sciences Teachers' Views on Teaching Socio- Scientific Issues in Genetics using an Inquiry Approach
}

\author{
Portia Ngwenya \\ University of Johannesburg, Johannesburg, South Africa \\ https://orcid.org/0000-0002-6685-2340 \\ Lydia Mavuru \\ University of Johannesburg, Johannesburg, South Africa \\ https://orcid.org/0000-0001-9099-0746
}

\begin{abstract}
The study sought to establish teachers' views about scientific inquiry in teaching genetics whilst addressing socio-scientific issues (SSIs). The argument was if teachers do not fully understand the holistic nature of scientific inquiry, it prevents them from using SSIs effectively to facilitate learners' understanding of abstract concepts. The study focused on genetics as a topic with SSIs and with abstract concepts difficult to present in concrete materials. Therefore, the paper aimed to learn about Life Sciences teachers' view in using scientific inquiry in teaching genetics whilst addressing socio-scientific issues. In an explanatory sequential mixed method research design, two questionnaires were administered to 100 Life Sciences teachers, to seek their views about scientific inquiry and understanding of socio-scientific issues respectively. Interviews were administered only to six teachers whose responses based on the analysis of data from questionnaires, were considered as informed, partially informed and naïve views. Lesson plans for selected teachers were analysed. The findings showed that the teachers were aware and appreciative of the inquiry-based approaches and socio-scientific issues embedded in genetics. The teachers however required extensive knowledge and skills on the procedures of inquiry that have to be employed when addressing socio-scientific in genetics. These findings inform teachers and teacher professional development programmes on the importance of context as the source of socio-scientific issues that tend to impact on learner understanding of concepts in topics such as genetics.
\end{abstract}

Keywords: genetics; scientific inquiry; Life Sciences; socio-scientific issues; teachers' views

\section{Introduction}

Learning of specific science concepts becomes meaningful and interesting to learners if it explains their life experiences (Kawasaki \& Sandoval, 2020). A 
deliberate use of scientific issues (socio-scientific issues) that require learners to engage in dialogue, discussion, and debate (Zeidler \& Nichols, 2009) enables learners to engage with and understand abstract concepts. Previous studies have shown how teachers are constrained to address socio-scientific issues (SSIs) in their teaching because they view science as an objective body of knowledge free of values (Reis \& Galvão, 2009); and some lack the pedagogical skills to deal with classroom discussions and debates that are stimulated by SSIs (Levinson \& Turner, 2001). The lack of pedagogical skills was also noted by Marbach-Ad and Stavy (2009) who found that teachers struggle with connecting the values or morals engrained within learners during the teaching and learning of abstract topics to ensure holistic conceptualisation of the scientific content. It shows that the teachers lack an understanding of the nature of science (NOS) yet NOS is meant to show an epistemological stance teachers have.

Because several studies have focused on teachers' acceptance of SSIs and their views about SSIs (Akbulut \& Demir, 2020; Nida et al., 2021; Parr, 2013), the current study focuses on teachers' views about the teaching of SSIs in genetics when using an inquiry approach. The argument is that whilst SSIs develop scientific literacy and bring the human aspect into science, i.e. its relevance and applicability in real life, the scientific inquiry approach affords the teachers the opportunity to engage learners in the construction of own knowledge without teachers imposing it on them. Scientific inquiry refers to the diverse processes through which science knowledge is produced and established as a result of the work of scientists (Hofstein \& Lunetta, 2003; National Research Council [NRC], 2011). The integration of SSIs when teaching science requires innovation in selecting suitable teaching strategies to be employed (Foulk et al., 2020). To integrate SSIs, Foulk et al. (2020) designed a timeline activity in which science learners could use to determine how historical events have influenced the American people's perceptions of nutrition. Such an activity helps teachers to integrate scientific concepts with real life events which can be economical, political or social in nature and it develops learners' decision making in real life (Foulk et al., 2020).

In a study to determine whether specific SSIs could increase the connection between students, science and real-life problems, Vasconcelos et al. (2018) reported the use of inquiry-based learning wherein groups of students from Porto Santo in Portugal, solved a case of using sand and clay in skincare. In addition to attaining scientific concepts, the findings showed how the inquiry-based activity developed learners' collaborative, communication, and argumentative skills (Vasconcelos et al., 2018). In addition, Vasconcelos et al. (2018) pointed out that such inquiry-based activities made learners to be critical, autonomous and creative, which Foulk et al. (2020) considered as essential competences for citizenship in society. The present study argues that if teachers do not fully understand the holistic nature of scientific inquiry, it prevents them from using SSIs effectively to facilitate learners' understanding of abstract concepts. This is illustrated in the context of teaching genetics. 


\subsection{Purpose of study}

Teachers' perceptions on the teaching of SSIs affect their understanding and implementation of the curriculum, and ultimately impact on the decisions they make during planning and preparation of their teaching (Ekborg et al., 2012; Sadler \& Zeidler, 2005). The purpose of the present study is to determine how inservice teachers view the teaching of abstract concepts in genetics (a topic embedded with SSIs) using inquiry approaches to foster meaningful understanding of abstract concepts in learners. It is through inquiry that teachers' and learners' attitudes can be transformed to allow for higher order reasoning and to help teachers address any misconceptions in learners. Consequently, the study was guided by the research question: How do teachers view the use of scientific inquiry in teaching genetics, whilst addressing socio-scientific issues?

\section{Literature Review}

\subsection{Socio-scientific issues in science teaching and learning}

SSIs have been described as authentic challenges in society which are connected to science (Owens et al., 2019). The SSIs in science emanate from the natural phenomena that try to connect scientific knowledge with the societal knowledge in answering scientific questions (Amos et al., 2017; Ariza et al., 2014). SSIs originate from the affective domain that influences teachers' views when teaching topics or concepts that have a bearing on learner emotions, attitudes and values (Abeysekera \& Dawson, 2015). These SSIs cannot be ignored in the Life Sciences classrooms because they are embedded in everyday life activities and experiences. They are derived from social challenges that have an effect on humans and ultimately on science knowledge development (Zeidler et al., 2005).

When addressed, SSIs engage learners in meaningful science learning as they require the use of evidence-based reasoning, and provide a context for understanding scientific information (Sadler, 2004; Zeidler, 2003). This is possible because learners develop a degree of moral reasoning when they discuss and evaluate ethical concerns before they make informed decisions in resolving real life problems (Zeidler \& Nichols, 2009). SSIs in science are vastly becoming more prominent in effective science teaching and learning as a way of acknowledging that science should be contextual in nature (Reis \& Galvão, 2009; Klassen, 2006; Rundgren \& Rundgren, 2010). They are fundamental in the selection of activities or tasks to be done, which depends upon the teachers' decision in the selection of material to scaffold learning (Reis \& Galvão, 2009). As early as 1993, Schein (1993) attested that children continuously learn from the environment to which they are exposed. Teachers' views about SSIs influence how science concepts are taught, conceptualised, and presented in the science classroom. Veugelers (2001) posited that SSIs are essential in developing learners into citizens that are critical thinkers, inquisitive about their environment, and are keen to solve societal problems. Addressing SSIs also relates the subject content to the reality of what happens or is experienced in the society, hence developing scientific literacy among learners (Kolsto, 2001; Millar \& Hunt, 2002; Monk \& Dillon, 2000).

Addressing SSIs when teaching science concepts is one thing, but learners' meaningful understanding is dependent on how the teachers scaffold knowledge 
from the known (SSIs) to the unknown (science knowledge) (Bosser, 2018). Saunders and Rennie (2011) noted that there are immense socio-scientific dilemmas that affect Life Sciences topics like cloning, genetic engineering, genetically modified organisms (GMOs), genetic diseases and reproductive technologies that require learners to be more aware and develop skills in addressing these controversial topics. The controversy in these Life Sciences concepts emanate from SSIs which tend to generate conflict in the classroom (Hancock et al., 2019).

\subsection{Teaching genetics, a topic with socio-scientific issues}

Genetics is the science of hereditary transmission from one organism to another where traits are inherited (Batten \& White, 2014). This genetic transmission can either occur in plants or animals in the form of similar or different traits due to parental attributes. Genetic concepts e.g. deoxyribonucleic acid (DNA) replication and mutations are abstract hence difficult to present in concrete materials. In a study carried out in South Africa, Kibuka-Sebitosi (2007) found that learners hold many misconceptions on genetics that relate to their lives. The sources of these misconceptions could also be pedagogical in nature in that the time between the presentation of some of the concepts in meiosis and those in genetics is too wide that learners forget and fail to make connections (Longden, 2010). Teachers should therefore use contextual materials that allow application and development of knowledge and inquiry skills that relate the concepts to learners' experiences and the environment they live in (Pukkilla, 2004; Sousa, 2017).

Addressing SSIs in genetics entails that the teachers should facilitate or guide the development of scientific knowledge through debates, discussions, and use of real life scenarios (Zeidler \& Nichols, 2009) to avert misconceptions that may arise. An example is when teaching cloning; teachers can guide learners to identify advantages and disadvantages of cloning whilst considering socially misconstrued ideas. Engaging learners in a discussion, and asking questions related to values or morality of cloning may promote critical thinking skills in learners. Globally, genetics has been taught through the use of debates, arguments, discussions, and story reflection (Klassen, 2006; Zeidler \& Nichols, 2009). Smith and Wood (2016) compared the teaching of genetics to undergraduate students in the past with those in the present and the findings revealed a shift from traditional methods of lecturing to more learner-centred methods. When involved, learners' interest, motivation and ultimately their achievement improve (Chu, 2008; Smith \& wood, 2016). In a study to determine South African learners' understanding about genetics and inheritance at grade 11 and 12 levels, Kibuka-Sebitosi (2007) found that there was a clash between the learners' beliefs on inheritance and scientific perspectives. Such conflict arises when scientific knowledge is at loggerheads with learners' preconceived ideas and beliefs particularly in concepts such as albinism, GMOs and cloning. Teachers need expert skills to address such issues for instance Nyamupangedengu (2015) showed how teachers could use "trigger incidents" that stimulate discussions, thereby developing critical thinking and reasoning in learners (p. 152). Such teaching strategies enhance learners' inquiry skills as they get to ask more questions which lead to the development of higher meta-cognitive reasoning and understanding of abstract genetics concepts. 
The teaching of topics with SSIs (e.g. genetics) using inquiry, plays a crucial role in bridging the gap that exists between content knowledge teachers and learners possess and the contextual knowledge in the society (Amos et al., 2017; Saunders \& Rennie, 2011). Teaching SSIs in science topics therefore requires learner autonomy afforded by inquiry-based approaches, which Pedaste et al. (2015) described as involving questioning, exploration, experimentation, interpretation and making conclusions. Addressing SSIs in genetics may be daunting to teachers particularly in classrooms where there is a multiplicity of cultures for example in the South African context. Previous studies showed that teachers faced many challenges when teaching genetics because of the abstract nature of the topic, complex terminologies associated with genetics, and differences in learners' contextual knowledge (Saunders \& Rennie, 2011).

\subsection{Scientific inquiry as the conceptual framework}

The present study is underpinned by the scientific inquiry as the conceptual framework. In school science, learners use inquiry approaches to understand how scientists investigate the natural world (Crawford, 2014; Penn et al., 2019). As learners enact science inquiry, they collect and analyse scientific data through observations for example, make conclusions, provide explanations for evidence and communicate their findings to others (Crawford, 2014).

The NRC (2011) and Next Generation of Science Standards for K-12, have advocated for the use of inquiry to develop metacognitive reasoning among learners while considering the contextual environment. According to Harlen (2014) and Ariza et al. (2014) the inquiry-based approaches help learners to acquire the necessary social problem-solving skills, which include questioning, identifying the problem, investigating, evaluating and hence developing analytical skills. This is possible because inquiry is a form of constructivist/interactionist approach (Dewey, 1996) that strives to develop learners cognitively and socially (Bryan \& Keys, 2001).

The current study presupposes that teaching SSIs in genetics through the use of inquiry-based approaches, will go a long way in improving learner understanding. Such a process will embrace the moral and value system essential for the development of more creativity and innovation among learners (Sadler et al., 2004). Teaching using inquiry does not only involve experimentation in a laboratory but can include the use of other sources to evoke the rise of new questions in science that can then be solved in relation to various societal issues (Amos \& Levinson, 2018; Galano et al., 2016; Sousa, 2017). Inquiry provides an opportunity for each individual learner to have different experiences, thereby catering for diverse attitudes, values, ethics, beliefs and epistemologies (Saunders \& Rennie, 2011). The process may probably alleviate the problem raised by Levinson and Turner (2001) who noted that teachers find it difficult to teach science while addressing SSIs that affect learner understanding in the science classroom. In support, Klassen (2006) indicated that if contextual knowledge (SSIs) is incorporated in science teaching, it develops critical thinking in learners particularly when teachers use inquiry-based approaches and activities that holistically develop learners emotionally, socially, and in terms of the scientific 
knowledge. Figure 1 illustrates how the use of inquiry approaches in addressing SSIs in genetics, can develop learners holistically.

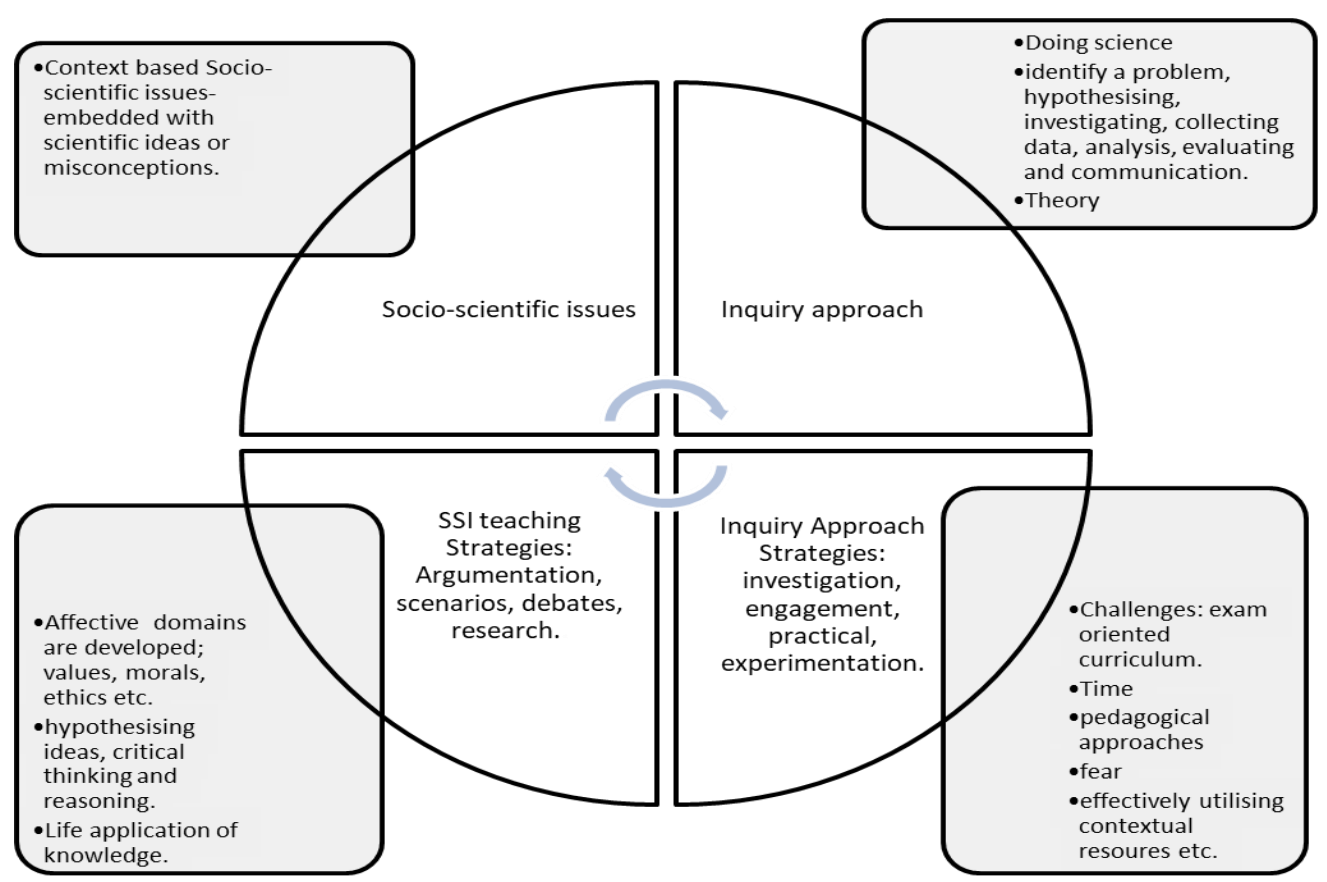

Figure 1: Holistic development through the blending of SSI and inquiry approach

The model in Figure 1 was developed by the researchers (authors of this article) using various literature sources (e.g. Ratcliffe \& Grace, 2003; Hancock et al., 2019) to explain how SSIs in genetics can be addressed using the inquiry approach. The blending ensures the misconceptions emanating from the social contexts learners bring from their upbringing, can be addressed through inquiry practical investigations which enable deeper understanding of scientific concepts in learners (Zeidler, 2003; Ratcliffe \& Grace, 2003). The use of inquiry approaches whilst addressing SSIs transforms learners' attitudes towards the subject and topic (transformation of the affective domain), which normally is an ignored area since most teachers focus on the cognitive domain. 
The authors assume that an integration of SSIs in genetics teaching will enhance the development of morals, values and ethics in learners (Abeysekera \& Dawson, 2015; Bryan \& Keys, 2001; Klassen, 2006). The rationale is that the blending of inquiry and SSIs enables teachers to develop effective pedagogical approaches and cut the amount of time they spend in teaching a particular topic. By establishing how teachers view the use of scientific inquiry in teaching genetics, whilst addressing socio-scientific issues, the present study is a precursor to the development of teacher professional development programmes on the teaching of SSIs using inquiry approaches.

\section{Methodology}

The study is located within pragmatic paradigm where the world is viewed as both real and socially constructed (Morgan, 2014). It follows an explanatory sequential mixed method research design (Creswell, 2014) in which the researchers first collected quantitative data, analysed the data, and then used the results in formulating questions used in collecting qualitative data from fewer individuals through interviews (Creswell, 2014; Subedi, 2016). The design was suited to this study as the quantitative data on teachers' views about SSIs and inquiry approach was explained by some of the findings from qualitative data.

\subsection{Selection of participants}

From the Johannesburg high school Life Sciences teachers, a group of 100 teachers was randomly selected, 50 from township schools (poorly resourced) and 50 from suburban schools (well resourced). The schools had a pass rate below $60 \%$ in Life Sciences. In the context of South Africa where the study was undertaken, the differences between township and suburban schools is that in addition to differences in resource availability township schools have larger class sizes ( $>45)$ compared to suburban schools ( $\leq 35)$ (Msila, 2009). It was important to determine these teachers' teaching patterns and approaches from the two contexts as this could have had an impact on learner performance. The sample was suitable for this study due to the high levels of diversity of teachers and learners in the schools in terms of language, values, ethnic, and cultural differences, which could influence the SSIs they held.

\subsection{Data collection, instruments and analysis}

\subsubsection{Administration of questionnaires}

To elicit teachers' understanding about scientific inquiry, only the first six questions of open ended questions of the Views of Scientific Inquiry (VOSI) instrument (Schwartzet al., 2008) (Appendix 1), were administered to the 100 inservice Life Sciences teachers. In addition, a questionnaire (Appendix 2), which sought the teachers' understanding of SSIs in genetics and their views about the teaching of SSIs using inquiry-based approaches, was administered. All questions sought open-ended responses from teachers, which ensured teacher autonomy in the reasoning and thinking, hence the teachers' responses were envisaged to be unbiased and reliable (Kothari, 2004). Both questionnaires were piloted first with 20 teachers who were not part of the participants and the results used to modify the clarity of the wording in the questionnaire items. 
Data from both questionnaires were analysed using the VOSI rubric with a number of possible responses for each category: naïve- 1 ; partially informed- 2; and informed-3. If the responses did not resonate with the accepted views, they were deemed as naïve and were allocated a score of 1 . A response was awarded a score of 2 for the partially informed view category if it had some aspects or contradictory perspective in light of the desired answers. To score 3 for the informed category, the response had to correspond with the targeted aspect of scientific inquiry, socio-scientific issues or the teaching of socio-scientific issues using inquiry. The two researchers for the present study and a science education specialist engaged in prior validation of 33 participants' responses to the questionnaires by reading through the transcripts and scored the teachers' responses independently using the scoring rubric, then compared the scores assigned in order to establish inter-coder reliability (Leedy \& Ormrod, 2014). By the end of this process the three independent coders, attained an inter-coder reliability above $80 \%$ agreement. The remaining 67 transcripts were then analysed by the researchers. The scores were then analysed using the IBM SPSS 26 software to generate descriptive statistics.

\subsubsection{Administration of interviews}

The results from the analysis of data from questionnaires were stratified into informed, partially informed and naïve views. A purposive stratified sampling technique was used to identify two teachers (one from township and the other from suburban school) from each stratum, and follow-up semi-structured interviews (Tongco, 2007), were administered to the six teachers individually. The interviews determined how the teachers' views influenced their instructional conceptions when teaching genetics whilst addressing SSIs using inquiry approaches. Qualitative data was essential in authenticating the data from the questionnaire responses given, hence making the data more realistic in nature to limit biases from some of the responses (Pluye \& Hong, 2014). Interviews were audio recorded and transcribed verbatim.

\subsubsection{Analysis of lesson plans}

Six lesson plans from the six interviewed teachers were analysed to authenticate the information from the questionnaires and interviews. The teaching strategies, examples and activities planned for the lessons were analysed to assess teachers' willingness to address SSIs in the genetics concepts to be taught. Textual data from both interviews and lesson plans were coded using manual coding (Saldana, 2009). They were then categorised using the three scales that indicated teachers' views as naïve, mixed and informed.

\subsubsection{Validity and reliability}

The use of different data collecting methods triangulated data and illuminated the validity and reliability of the data as issues raised in the questionnaires were authenticated by what the teachers said in the interviews and what they wrote in their lesson plans (Abeysekera \& Dawson, 2015). As such, the views teachers held about scientific inquiry in teaching genetics, a topic embedded with SSIs were explicitly determined. Any identified discrepancies required administering a second round of interviews to ascertain them and only one participant warranted 
a second round of interviews. Ethical considerations were adhered to as stipulated by the Research Ethics Committee.

\section{Results}

The results on the teachers' views about scientific inquiry in teaching genetics while addressing socio-scientific issues are presented using three subheadings, which are: Teachers' understandings of scientific inquiry; Teachers' understandings of socio-scientific issues; and Teachers' understandings of addressing socio-scientific issues embedded in GMOs a genetics concepts embedded with SSIs.

\subsection{Teachers' understandings of scientific inquiry}

There were more teachers who held informed views about what scientific inquiry is $(97.7 \%)$ and knowledge of how it could be used in teaching genetics $(90.9 \%)$ compared to those who held informed views about the sequence of scientific steps $(31.8 \%)$. The teachers who indicated that the inquiry approach requires a series of sequential steps that cannot be changed despite the changes in the contextual knowledge acquired (68.2\%), showed a rigid way of doing scientific inquiry. This was categorised as naïve because methods and sequencing of steps depend on the aims and objectives investigated at a particular time. These teachers did not consider that scientific inquiry steps can resume at any step depending on the context that is being investigated. For example, a scientist can start by analysing already collected data and make inferences. Table 2 shows an example of an analysis of some of the teachers' responses to the question: If several teachers in different contexts ask the same questions and use the same procedure, will they arrive at the same conclusion?

Table 1: An example of analysis of teacher responses

\begin{tabular}{|c|c|c|c|}
\hline $\begin{array}{l}\text { Teachers' } \\
\text { pseudonyms }\end{array}$ & Responses & $\begin{array}{l}\text { Teachers' } \\
\text { scored } \\
\text { views }\end{array}$ & Reasons for the scores \\
\hline Curtis & $\begin{array}{l}\text { Yes, the principles of } \\
\text { scientific inquiry are the } \\
\text { same hence the outcome } \\
\text { will be the same. }\end{array}$ & 1 & $\begin{array}{l}\text { Naïve view. The teacher did not } \\
\text { consider the influence of the } \\
\text { contextual knowledge influences. }\end{array}$ \\
\hline Tebogo & $\begin{array}{l}\text { Use of same questions } \\
\text { using the same } \\
\text { procedure therefore } \\
\text { conclusions should be } \\
\text { the same. }\end{array}$ & 1 & $\begin{array}{l}\text { Naïve view. The teacher's response } \\
\text { lacks consideration of individual } \\
\text { views, contexts or the resources that } \\
\text { can give different results. }\end{array}$ \\
\hline $\mathrm{Neo}$ & $\begin{array}{l}\text { I don't think so because } \\
\text { they are asking the } \\
\text { same question coming } \\
\text { from different contexts }\end{array}$ & 3 & $\begin{array}{l}\text { Informed view because the teacher is } \\
\text { aware of the influence emanating } \\
\text { from different contexts }\end{array}$ \\
\hline Theodore & $\begin{array}{l}\text { Yes but it depends on } \\
\text { the knowledge and skill } \\
\text { of the teacher }\end{array}$ & 2 & $\begin{array}{l}\text { Partially informed view because the } \\
\text { teacher's knowledge and skills are } \\
\text { not the only things that affect the } \\
\text { development of contextual } \\
\text { knowledge. Materials and learner } \\
\text { knowledge influence the outcomes. }\end{array}$ \\
\hline
\end{tabular}


The finding that some teachers have partially informed and naïve views has implications for the manner in which they design scientific inquiry activities for their learners. These teachers could give learners rigid steps to follow without considering learners' autonomy.

\subsection{Teachers' understandings of socio-scientific issues}

Teachers' views about socio-scientific issues embedded in genetics are important as teachers' views influence the manner in which they teach the concepts. Table 2 presents the distribution of teachers' views about each question.

Table 2: Teachers' understandings of socio scientific issues in the topic albinism

\begin{tabular}{|c|c|c|c|}
\hline & $\begin{array}{c}\text { Naïve } \\
\%\end{array}$ & $\begin{array}{c}\text { Partially } \\
\text { informed \% }\end{array}$ & $\begin{array}{c}\text { Informed } \\
\%\end{array}$ \\
\hline $\begin{array}{l}\text { 1. Learners' environment influences content and } \\
\text { material taught in genetics }\end{array}$ & 15.9 & 0 & 84.1 \\
\hline $\begin{array}{l}\text { 2. The topic genetics considers learners' diverse } \\
\text { context }\end{array}$ & 18.2 & 25 & 56.8 \\
\hline 3. Instructional time should be spent teaching SSIs & 11.4 & 9.1 & 79.5 \\
\hline 4. Scientific inquiry is the best way to teach SSIs & 6.8 & 13.6 & 79.5 \\
\hline $\begin{array}{l}\text { 5. How albinism can be taught in a class where } \\
\text { there is an albino child }\end{array}$ & 9.1 & 11.4 & 79.5 \\
\hline $\begin{array}{l}\text { 6. Do you think the affected learner (learner with } \\
\text { albinism) will take offence? If so how can you } \\
\text { minimise the discomfort of the learner(s)? }\end{array}$ & 15.9 & 4.5 & 79.5 \\
\hline Average & 12.9 & 10.6 & 76.5 \\
\hline
\end{tabular}

Table 2 shows that teachers held more informed views about socio-scientific issues (average of $76.5 \%$ ) compared to their informed views about scientific inquiry (average $72.73 \%$ ) in the previous section. This could be because socioscientific issues are engrained in their everyday life experiences as members of the society. They are therefore cautious of them as they struggle in their classrooms when dealing with such issues. There was however a high percentage $(43.2 \%)$ of naïve and partially informed views in response to question 2 compared to all the questions. The question required teachers to share their views on whether the South African Life Sciences curriculum considers learners' diverse/multiplicity of context with regard to the topic genetics. A point to note is that in one of its specific aims the curriculum stipulates the importance of "understanding of applications of Life Sciences in everyday life" (DBE, 2011, p. 13). In the content area the curriculum only refers to consequences of abnormal meiosis in the case of Down Syndrome and harmful mutations in the case of conditions such as albinism. Nothing is however mentioned about how the teachers can navigate such sensitive issues in the classroom. Hence the curriculum is silent about how the teaching of SSIs should be implemented in the classrooms, leaving individual teachers to identify the suitable strategies and activities by themselves. In the interviews the teachers bemoaned the insensitivity displayed by the Life Sciences curriculum when dealing with diversity in the classroom. An example given was that the curriculum is silent about how teachers should teach the concept albinism considering that there could be learners whose family members are albinos and let alone when there is a learner in the classroom with the condition. Some 
teachers pointed out that genetic disorders such as albinism are very sensitive and are controversial concepts of genetics to teach. An example is depicted by one participant who said, "I am a human being and in as much as I want to effectively teach these concepts, there are things that cannot be discussed due to community beliefs about albinism."

Four teachers who were less experienced (less than five years' teaching experience) and two teachers with 11 to 20 years' experience, displayed naïve views to the question: There is an albino child in your Life Sciences class, how would you approach the concept of albinism in that class? The teachers' responses were that it is important to ask the 'affected' learner to explain their condition to the rest of the class. This was categorised as a naïve perspective due to lack of respect and consideration of the individual learner or the psychological, emotional or social impact this kind of action could have on the learner. One of the teachers pointed out in the interviews that how a teacher introduces and engages learners when teaching controversial topics makes a difference. The teacher said, "It's the way the teacher does it, you have to be sensitive and you can never use a child in a class as an example." Three of the interviewed teachers mentioned the importance of engaging learners in research, discussion, debate and even argumentation when teaching a controversial topic so that learners can share their view points. Such activities help learners to search for information, engage with ideas from other learners and at the end determine the most appropriate explanation to what they will be dealing with. One participant gave an example of beliefs learners bring to the Life Sciences classroom which the teacher alone cannot tackle. She said that several of her learners once said, "Ma'am do you realise that the spirits or souls of albinos don't go anywhere after death, they get caught up in the spiritual world." Another participant mentioned that her learners thought that albinism is a curse on the parents of such a child. Given such beliefs, it means learners with albinism will be isolated and stigmatised. Such findings show that there are many SSIs embedded in the topic genetics. If such concepts are not explored using the appropriate methods, learners may remain with these naïve ideas, which can be very dangerous particularly in today's society where there is a lot of discrimination and violence against certain groups of people.

\subsection{Addressing socio-scientific issues using inquiry approach}

The questions given to teachers were meant to assess their views on how socioscientific issues could be addressed. From the teachers' responses, one could deduce their orientation with regard to the use of inquiry-based approaches in their teaching of the concepts as they explained how they handled different ideas on genetics brought to the classroom. Table 3 shows the distribution of teachers' views about addressing socio-scientific when teaching concepts on genetically modified organisms (GMOs). The teachers were responding to questions asked in the SSIs questionnaire about scenarios of two groups of researchers. One group of researchers presents the benefits of GMOs in terms of quality food taste and disease resistant crops hence saving on pesticide usage. The other group of researchers insists that there have not been conclusive studies to show the longterm effects of GMOs on both plants and animals. 
Table 3: Teachers' understandings on the teaching of GMOs using inquiry approach

\begin{tabular}{|c|c|c|c|}
\hline Item & Naïve \% & $\begin{array}{l}\text { Partially } \\
\text { informed } \\
\%\end{array}$ & $\begin{array}{l}\text { Informed } \\
\%\end{array}$ \\
\hline $\begin{array}{l}\text { 1. How would you explain to the learners the } \\
\text { differences in the claims made by the two groups } \\
\text { of researchers on GMOs? }\end{array}$ & 6.8 & 29.5 & 63.6 \\
\hline $\begin{array}{l}\text { 2. One teacher decided to task learners to record } \\
\text { the views of their community members about the } \\
\text { GMOs and compiled a report. Is this a scientific } \\
\text { inquiry? }\end{array}$ & 18.2 & 6.8 & 75 \\
\hline $\begin{array}{l}\text { 3. Do you think that the strategy recommended } \\
\text { above is applicable in South African context? Why } \\
\text { and why not, give reasons and examples. }\end{array}$ & 59.1 & 6.8 & 34.1 \\
\hline $\begin{array}{l}\text { 4. Is it important to discuss ethical issues associated } \\
\text { with the process of genetic engineering with the } \\
\text { learners? Explain your answer. }\end{array}$ & 4.5 & - & 95.5 \\
\hline $\begin{array}{l}\text { 5. If learners bring in their conflicting views in the } \\
\text { classroom, would you consider the discussion and } \\
\text { analysis as scientific inquiry? Explain your answer. }\end{array}$ & 4.5 & 6.8 & 88.6 \\
\hline Average & 18.6 & 9.98 & 71.4 \\
\hline
\end{tabular}

Whilst the majority of the teachers displayed informed views about the teaching of GMOs (an average of $71.4 \%$ ), there was quite a number (59.1\%) who held naïve views about the applicability of the suggested teaching strategy in the South African context. The strategy required learners to interview and record community members' views about GMOs. In the interviews when asked about the usefulness of such a strategy, most of the teachers were quick to argue that people in communities were not well informed about GMOs, hence learners would not collect reasonable information. It shows that the teachers do not have confidence in the level of knowledge community members possess, which is unfortunate because teachers are making decisions based on assumptions. Such attitudes undermine the role the community plays in the education of learners. Another point is that these teachers display naïve views about research because by carrying out an inquiry, you do not expect to get only the results you expected and that even from unexpected responses, learners can obtain valuable information.

Most teachers held informed views on the advantages and disadvantages of genetic engineering while citing examples such as "the need to cater for the demand in food production, genetic engineering causing some diseases, genetic engineering having negative effects on health, and also causing genetic mutation of plants." Only a few mixed views were noted in relation to the curriculum, when answering the question on whether "the strategy of teaching socio-scientific issues using inquiry is applicable in South African context." The responses included the idea that the strategy depends on the society; the knowledge on curriculum content intensity; time frames; and assessments. The issues about diversity of societal knowledge were not taken into consideration. 
Based on the analysis of teachers' lessons, the teachers held informed views about the methods used in teaching SSIs and their application in teaching and learning. They gave examples like the use of videos, technology or internet in the Life Sciences classrooms. Teachers however cited the availability of resources, sizes of the classrooms, experience, technology, support systems from home, school or community, learners' interests and attitudes, as important.

During interviews teachers had various views when asked the question: do you think that the methods used in teaching SSIs, should be universal across the country? Those who showed informed views argued that because there are different teaching and learning environments, teaching should cater for the different contexts by using examples familiar to the learners. For instance, one of the teachers said, "If teaching at a school in the coast, then use examples from the marine world." Those who opted for universal teaching methods argued that learners write similar examinations at the end of the year, which do not provide for the different contexts in which learners are taught. Such a justification shows that the teachers do not realise that the use of contextual materials allow learners to apply and develop knowledge and inquiry skills that relate the concepts to learners' experiences and the environment they live in. One of the teachers, indicated that learners have inquisitive minds therefore, it is imperative that learners be engaged in inquiry activities to ensure knowledge acquisition. Some of the 'prerequisite characteristics' of a Life Sciences teacher mentioned by the teachers included: being an inquisitive teacher; having the ability to elicit learners' thought processes before teaching any content; and considering diverse learners' context. The teachers' responses are aligned to the scientific inquiry-based approaches.

Other teachers pointed out that scientific inquiry engages learners in discovering knowledge by themselves. The teachers justified this particularly when teaching controversial topics that are embedded with socio-scientific issues where learners bring in different ideological thoughts and practices based on their upbringing. One teacher pointed out that, "There are SSIs that when presented from the teachers' perspective, might have an impact on some of the learners' rights within the classroom". The teacher suggested indulging or engaging learners in learnercentred discussions, such as argumentation, giving learners an opportunity to debate issues and explore their thought processes, whilst the teacher acts as an observer and facilitator or guide. One participant reiterated, "Learners brainstorm on these socio-scientific issues and get to understand the underlying scientific ideas inherent in those issues". One of the teachers however cautioned that there is need for the teacher to be attentive and be wary of learners who might take issues personally and get offended in the teaching and learning process.

\section{Discussions}

The majority of teachers had informed views about addressing socio-scientific issues in the topic genetics. This was shown in an example where $84.1 \%$ of the teachers thought that learners' environment influences the content and material that can be taught in genetics. This is attested by the majority of teachers $(95.5 \%)$ who held informed views about the importance of discussing with the learners 
the ethical issues associated with the process of genetic engineering. Such findings are supported by previous researchers who noted that the teaching of topics embedded with SSIs using inquiry plays a crucial role in bridging the gap that exists between content knowledge of the teachers and learners with that of contextual knowledge in the society (e.g. Amos et al., 2017; Saunders \& Rennie, 2011). It is through inquiry that teachers' and learners' attitudes can be transformed to allow for higher-order reasoning as SSIs are fundamental in developing conceptual understanding, particularly in the topic genetics (Schalk, 2012).

Whilst the majority of the teachers displayed informed views about the inquirybased approaches, there were some teachers who showed naïve views. For instance, when asked if they would consider discussion and analysis as scientific inquiry when learners bring in their conflicting views in the classroom, the teachers who showed naïve views indicated that they would not consider it at all. They viewed discussion and analysis as intrusive methods particularly when dealing with sensitive issues. Such teacher sentiments are shared by Juntunen and Aksela (2013), who found that inquiry approaches are the most effective methods but the main issue is on how teachers use them in teaching abstract topics like genetics to scaffold learning. These teachers' views could be because of the context in which they find themselves in for instance Pope (2017) pointed out that issues of ethics, morality and religion play an role in the pedagogical practices of teachers in the classroom.

The majority of teachers displayed naïve understanding about the use of inquiry approaches in teaching GMO, a concept with SSIs. They indicated that engaging learners in recording the views of their community members is not a scientific inquiry. This indicated that teachers' reasoning on inquiry in teaching genetics is based on testing in a laboratory to prove an idea without developing critical thinking and reasoning (Setty \& Kosinki-Collins, 2015; Tsai, 2018; Amos et al., 2017; Ariza et al., 2014). There were a few teachers who were sceptical about using inquiry approaches such as engaging learners in an argumentation when addressing controversial concepts in genetics thereby denying learners an opportunity to make informed decisions. This defeats the affordances of inquirybased approach which can develop metacognitive critical thinking and reasoning in learners (Crawford 2014; Balim \& Ozcan, 2014). The teachers' naïve views are of concern considering that teachers' views on the moral challenges associated with teaching genetics may affect the teaching of these abstract concepts (Zeidler \& Nichols, 2009). It is however important to consider these teachers' naïve views as in some cultures, argumentation is considered confrontational which Hewson (2015) considered unAfrican as it goes against the African values of communal sharing and respecting of others. It could be that these teachers felt that argumentation goes against the essence of harmony in their science classrooms.

When asked about their thoughts on whether the teaching of socio-scientific issues should be universal across the country, teachers with informed views argued for contextualised teaching. The findings from these teachers are in line with the previous studies by Abeysekera and Dawson (2015), Sousa (2017) and Kibuka- 
Sebitosi (2007) who found that the use of contextual knowledge that learners bring to the classroom, fosters metacognitive reasoning among learners. On the other hand, the teachers who held naïve views argued for universal teaching since learners would write the same examinations at the end of year. In this particular case, teachers showed a lack of understanding on how controversial issues can be handled in the classroom and is likely to negatively affect learners' acquisition and understanding of scientific knowledge (Setty \& Kosinki- Collins, 2015).

The teachers were forthcoming when it comes to teaching strategies that foster inquiry-based learning in the Life Sciences classroom particularly when it comes to giving learners autonomy to engage with their thought processes. Teachers indicated the utility value of inquiry strategies when addressing socio-scientific issues and brainstorming on controversial concepts such as albinism and GMOs. The strategies mentioned included learner-centred discussions, use of argumentation and debate whilst the teacher acts as an observer and facilitator or guide. This shows how scientific inquiry is multifaceted in nature and how it has become one of the most advocated approaches for science teaching and learning in today's classrooms (Harlen, 2014; Ariza et al. 2014; Lederman, Lederman \& Antink, 2013).

\section{Pedagogical Implications and Recommendations}

The study sought to establish Life Sciences teachers' views on the use of scientific inquiry in teaching genetics, whilst addressing socio-scientific issues. The findings showed that teachers' limited understanding of the holistic nature of scientific inquiry prevents them from addressing SSIs effectively to facilitate learners' understanding of abstract concepts in genetics. Whilst the study found that teachers held informed views about what scientific inquiry is and knowledge of how it could be used in teaching genetics, they however showed a limited understanding on how the sequence of the steps in scientific inquiry could be implemented in the classroom. As a result, teachers were not convincing in their reports on how SSIs in genetics could be taught using an inquiry approach. From a practitioner's point of view, teachers' views about socio-scientific issues in some science topics should be taken into consideration as views influence the manner in which teachers teach the concepts. Failure to consider teachers' views may result in teachers' apathy in utilising pedagogical strategies which engage learners in the desired analytical and critical thinking. Teachers therefore require professional development forums where they interrogate their views and practices when teaching controversial topics with the guide of teacher educators and curriculum specialists.

Future studies should extend the study to include learners' views and also observe the teachers' practices whilst they engage learners in inquiry activities in order to address socio-scientific issues, which are not only embedded in the topic genetics but other topics as well. The study contributes to a body of knowledge on teachers' perspectives on the strategies that foster inquiry-based learning that give learners autonomy to engage with their thought processes when addressing socio-scientific issues and brainstorming on controversial science concepts. 


\section{Acknowledgement}

The authors would like to extend their gratitude to Life Sciences teachers in Johannesburg who participated in the survey for this study.

\section{References}

Akbulut, H. I., \& Demir, O. (2020). Science teachers' views of socio scientific issues. International Journal of Progressive Education, 16(1), 237-256. https:// doi.org.10.29329/ijpe.2020.228.17

Abeysekera, L., \& Dawson, P. (2015). Motivation and cognitive load in the flipped classroom: Definition, rationale and a call for research. Higher Education Research \& Development, 34(1), 1-14. https:/ / doi.org.10.1080/07294360.2014.934336

Amos, R., Christodoulou, A., Grace, M., \& Levinson, R. (2017). Teaching science using socioscientific inquiry based learning: UK pre-service teachers perspectives. Southampton, UK: University College London.

Amos, R., \& Levison, R. (2018). Socio-scientific inquiry based learning (Ssibl): Gearing social action to scientific knowledge. New Perspectives in Science Education, Conference Proceedings, 590-594.

Ariza, M. R., Abril, A. M., Quesada, A., \& García, F. J. (2014). Bridging inquiry based learning and science education on socio scientific issues. Contributions to the PARRISE project. In L. G. Chova, A. López Martínez \& I. Candel Torres (Eds.), Proceedings of the 8th International Technology, Education and Development Conference (pp. 25992607). Valencia, Spain: IATED Academy.

Balim, A. G., \& Ozcan, E. (2014). Pre-service science teachers' views towards socio-scientific issues. International Conference, New Perspectives in Science Education, Conference Proceedings: Dokuz Eylul University Scientific Research Project.

Batten, J., \& White, C. C. (2014). Exploring genetics across the middle school science and math curricula. Raleigh, NC: College of Agriculture and Life Sciences, NC State University.

Bryan, L. A., \& Keys, C. W. (2001). Co-constructing inquiry based science with teachers essential research for lasting reform. Journal of Research in Science teaching, 38(6), 631-645. https://doi.org.10.1002/tea.1023

Bosser, U. (2018). Exploring the complexities of integrating socio-scientific issues in teaching. Kalmar, Sweden: Linnaeus University Press.

Crawford, B. A. (2014). From Inquiry to Scientific Practices in the Science Classroom. In N. G. Lederman \& S. K. Abell (Eds.), Handbook of Research on Science Education, Vol. II pp. 529-556. New York: Routledge.

Chu, H. N. R. (2008). Shyness and EFL learning in Taiwan: A students' use of strategies, foreign language anxiety, motivation, and willigness to communicate [PhD Thesis, The University of Texas at Austin, Texas, United States].

Creswell, J. W. (2014). Research design: Qualitative, quantitative and mixed approaches (4th Ed.). Thousand Oaks, California: Sage Publications.

Dewey, J. (1996). Theory of the moral of Life. New York: Holt Rinehart \& Winston Inc.

Schein, E. H. (1993). On dialogue, culture, and organisational learning. Organizational Dynamics, 22(2), 40-51. https:/ / doi.org/10.1016/0090-2616(93)90052-3

Ekborg, E., Ottander, C., Silfver, E., \& Simon, S. (2012) Teachers' experience of working with socio-scientific issues: A large scale and in depth study. Research in Science Education, 43, 599-617. https://doi.org/10.1007/s11165-011-9279-5

Foulk, J. A., Friedrichsen, P. J., \& Sadler, T. D. (2020). Science in socio-scientific issues: Teaching with a timeline activity. The Science Teacher, 35-39. 
Galano, S., Zappia, A., Smaldone, L., \& Testa, I. (2016). Secondary students' views about scientific inquiry. Naples, Italy: Department of Physics, University Federico II.

Hancock, T. S., Friedrichsen, P. J., Kinslow, A. T., \& Sadler, T. D. (2019). Selecting socioscientific issues for teaching: A grounded theory study of how science teachers collaboratively design SSI-based curricula. Science \& Education, 28, 639-667. https://doi.org/10.1007/s11191-91-091-00065-x

Harlen, W. (2014). Helping children's development of inquiry skills. Inquiry in primary science education (IPSE), 1, 5-19.

Hewson, M. G. (2015). Embracing indigenous knowledge in science and medical teaching. Cultural Studies of Science Education. Springer. https://doi.org/10.1007/978-94017-9300-1_11

Hofstein, A., \& Lunetta, V. N. (2003). The laboratory in science education: Foundations for the twenty-first century. Science Education, 88(1), 28-54. https://doi.org/10.1002/sce.10106

Juntunen, M., \& Aksela, M. (2013). Life-cycle analysis and inquiry-based learning in chemistry teaching. Science Education International, 24(2), 150-166.

Kawasaki, J., \& Sandoval, W. A. (2020). Examining teachers' classroom strategies to understand their goals for student learning around science practices in the Next Generation Science Standards. Journal of Science Teacher Education, 31(4), 384-400. https:// doi.org/10.1080/1046560x.2019.1709726

Kibuka-Sebitosi, E. (2007). Understanding genetics and inheritance in rural schools. Educational Research, 41(2), 56-61. https://doi.org/10.1080/00219266.20079656063

Klassen, S. (2006). A theoretical framework for contextual science teaching. Interchange, 37(1), 31-62. https://doi.org/10.1007/s10780-006-8399-8

Kolsto, S. D. (2001). Scientific literacy for citizenship: Tools for dealing with the science dimension of controversial socio-scientific issues. Science Education, 85(3), 291-310. https://doi.org/10.1002/sce.1011

Setty, S., \& Kosinki-Collins, M. S. (2015). A model inquiry-based genetics experiment for introductory biology students: Screening for enhancers and suppressors of $\begin{array}{llll}\text { Ptpmeg. American } & \text { Biology }\end{array}$ https://doi.org/10.1525/abt.2015.77.1.6

Kothari, C. R. (2004). Research methodology: Methods and techniques (2 ${ }^{\text {nd }}$ ed.). New Delhi: New Age International.

Lederman, N. G., Lederman, J. S., \& Antink, A. (2013). Nature of science and scientific inquiry as contexts for the learning of science and achievement of scientific literacy. International Journal of Education in Mathematics, Science and Technology, 1(3), 138-147.

Leedy, P. D., \& Ormrod, J. E. (2014). Practical Research: Planning and Design (10th ed.). New York: Pearson.

Levinson, R., \& Turner, S. (2001). Valuable lessons: Engaging with the social context of science in schools - Recommendations and summary of research findings. London: The Wellcome Trust (Online). http://www.wellcomeac.uk/stellent/groups/corporatesite/@msh_peda/docu ments/web_-document/wtd003446.pdf

Longden, B. (2010). Genetics- are there inherent learning difficulties? Journal of Biological Education, 16(2), 135-140. https:// doi.org/10.1080/00219266.1982.9654439

Marbach-Ad, G., \& Stavy, R. (2009). Student cellular and molecular explanation of genetic phenomena. Journal of Biological Education, 34(4), 200-205. https://doi.org/10.1080/00219266.2000.9655718

Millar, R., \& Hunt, A. (2002). Science for public understanding: A different way to teach and learn science. The School Science Review 83(304), 35-42. 
Monk, M., \& Dillon, J. (2000). The nature of science knowledge. In M. Monk \& J. Osborne (Eds). Good practice in science teaching: What research has to say (pp. 72-78). Buckingham: Open University Press.

Msila, V. (2009). School choice and intra- township migration: Black parents scrambling for quality education in South Africa. Journal of Education, 46, 81-98.

Morgan, D. L. (2014). Pragmatism as a paradigm for social research. Qualitative Inquiry, 20(8), 1045-1053. https://doi.org/10.1177/1077800413513733

National Research Council (NRC). (2011). Successful K-12 stem education: Identifying effective approaches in Science, Technology, Engineering, and Mathematics. Washington, DC: NAP.

Nida, S., Mustikasari, V. R., \& Eilks, I. (2021). Indonesian pre-service science teachers' views on socio-scientific issues based science learning. Eurasia Journal of Mathematics, Science and Technology Education, 17(1), em1932. https://doi.org/10.29333/ejmste/9573

Nyamupangedengu, E. (2015). Teaching genetics to pre-service teachers: A teacher educator's approach to transformative practice through self-study. Doctoral thesis submitted at the University of Witwatersrand, Johannesburg, South Africa. Available at http://wiredspace.wits.ac.za/handle/10539/19606

Owens, D. C., Sadler, T. D., \& Friedrichsen, P. J. (2021). Teaching practices for enactment of socio-scientific issues instruction: An instrumental case study of an experienced biology teacher. Research in Science Education, 51, 375-398. https:// doi.org/10.1007/s11165-018-9799-3DO

Parr, J. C. (2013). Views of socioscientific issues among educators: The willingness of teachers to accept SSIs into the classroom and the reason underlying those beliefs. Dissertation submitted to University of Southern Mississippi: The Aquila Digital Community. https://aquila.usm.edu/dissertations/530

Pedaste, M., Mäeots, M., Siiman, L. A., de Jong, T., Van Riesen, S. A. N., Kamp, E. T., Manoli, C. C., Zacharia, Z. C., \& Tsourlidaki, E. (2015). Phases of inquiry-based learning: Definitions and the inquiry cycle. Educational Research Review, 14, 47-61. https://doi.org/10.1016/j.edurev.2015.02.003

Penn, M., Ramnarain, U., \& Wu, H-K. (2019). The Relationship between Grade 12 learners' understandings about scientific inquiry and achievement in Physical Sciences. Proceedings of the 27th annual meeting of the Southern African Association of Research in Mathematics and Science Technology Education (SAARMSTE) Conference. University of Kwa-Zulu Natal: Durban, South Africa 15-17 January 2019.

Pope, T. (2017). Socioscientific Issues: A framework for teaching ethics through controversial issues in science. Teach Journal of Christian Education, 11(2), 42-49.

Pukkilla, P. J. (2004). Introducing student inquiry in large introductory classes. Genetics. 166(1), 11-18. https://doi.org/10.1534/genetics.166.1.11

Pluye, P., \& Hong, Q. N. (2014). Combining the power of stories and the power of numbers: Mixed methods research and mixed studies reviews. Annual Review Public Health, 35, 29-45. https://doi.org/10.1146/annurev-publhealth-032013182440

Ratcliffe, M., \& Grace, M. (2003) Science education for citizenship: Teaching socio-scientific issues. Maidenhead, PA: Open University Press.

Reis, P., \& Galvão, C. (2009). Teaching controversial socio-scientific issues in biology and geology classes: A case study. Electronic Journal of Science Education, 13(1), 162-185. http://hdl.handle.net/10451/4612 
Sadler, T. D. (2004). Informal reasoning regarding socioscientific issues: A critical review of research. Journal of Research in Science Teaching, 41(5), 513-536. https://doi.org/10.1002/tea.20009

Sadler, T. D., Chambers, F. W., \& Zeidler, D. L. (2004). Student conceptualisations of the nature of science in response to a socio-scientific issue. International Journal of Science Education, 26(4), 387-409. https://doi.org/10.1080/0950069032000119456

Sadler, T. D., \& Zeidler, D. L. (2005). The significance of content knowledge for informal reasoning regarding socioscientific issues: Applying genetics knowledge to genetic engineering issues. Science Education, 89(1), 71-93. https://doi.org/10.1002/sce.20023

Saldana, J. (2009). The coding manual for qualitative researchers. London: Sage.

Saunders, K. J., \& Rennie, L. J. (2011). A pedagogical model of ethical inquiry in socioscientific issues in science. Research Science Education, 43, 253-274. https://doi.org/10.1007/s11165-011-9248-z

Schalk, K. A. (2012). A socioscientific curriculum facilitating the development of distal and proximal NOS conceptualizations. International Journal of Science Education, 34 (1), 1-24.

Sousa, C. (2017). Integrating bioethics in sciences' curricula using values in science and socioscientific issues. Multidisciplinary Journal for Education, Social and Technological Sciences, 4(1), 122-134. https:/ / doi.org/10.4995/muse.2017.6481

Smith, M. K., \& Wood, W. B. (2016). Teaching genetics: Past, present, and future. Genetics Society of America, 204, 5-10. https://doi.org/10.1534/genetics.116.187138

Subedi, D. (2016). Explanatory sequential mixed method design as the third research community of knowledge claim. American Journal of Educational Research 4(47), 570-577. https://doi.org/10.12691/education-4-7-10

Schwartz, R. S., Lederman, N. G., \& Lederman, J. S. (2008). An instrument to assess views of scientific inquiry: The VOSI questionnaire. Paper presented at the annual meeting of the National Association for Research in Science Teaching, Baltimore, MD.

Tongco, M. D. C. (2007). Purposive sampling as a tool for informant selection. Ethnobotany Research and Applications, 5, 147-158. http://hdl.handle.net/10125/227

Tsai, C. (2018). The effect of online argumentation of socioscientific issues on students' scientific competencies and sustainability attitudes. Computers and Education, 116, 14-27. https://doi.org/10.1016/j.compedu.2017.08.009

Vasconcelos, C., Cardoso, A., \& Vasconcelos, M. L. (2018). Socio-scientific issues and scientific literacy. 11th International Conference of Education, Research and Innovation, November 12th-14th, Seville, Spain.

Veugelers, P. J. (2001). Proximate and contextual socioeconomic determinants of mobility: Multilevel approaches in a setting with universal health care coverage. American Journal of Epidemiology, 154(8), 725-732. https://doi.org/10.1093/aje/154.8.725

Zeidler, D. L. (2003). The role of moral reasoning on socio-scientific issues and discourse in science education. London: Kluwer Academic Publishers.

Zeidler, D. L., Sadler, T. D., Simmons, M. L., \& Howes, E. V. (2005). Beyond STS: A research-based framework for socio-scientific issues education. Science Education, 89(3), 357-377. https://doi.org/10.1002/sce.20048

Zeidler, D. L. \& Nichols, B. H. (2009). Socioscientific issues: Theory and practice. Journal of Elementary Science Education, 21(2), 49-58. https://doi.org/10.1007/bf03173684 
Appendix 1: Views of Scientific Inquiry (VOSI) instrument (Schwartz, Lederman \& Lederman, 2008)

1. What types of activities do scientists do to learn about the natural world? Be specific about how they go about their work.

2. What scientists choose to study and how they learn about the natural world may be influenced by a variety of factors. How do scientists decide what and how to investigate? Describe all the factors you think influence the work of scientists. Be as specific as possible.

3 (a) Write a definition of a scientific experiment?

A scientific experiment is......

b) Give an example from something you have done or heard about in science that illustrates your definition of a scientific experiment.

c) Explain why you consider your example to be a scientific experiment.

4. A person interested in birds looked at hundreds of different types of birds who eat different types of food. He noticed that birds who eat similar types of food, tended to have similar shaped beaks. For example, birds who eat hard shelled nuts have short, strong beaks, and birds who eat insects from tide pools have long, slim beaks. He concluded that there is a relationship between beak shape and the type of food birds eat.

a) Do you consider this person's investigation to be scientific? Please explain why or why not.

b) Do you consider this person's investigation to be an experiment? Please explain why or why not.

5. Some people have claimed that all scientific investigations must follow the same general set of steps or method to be considered science. Others have claimed there are different general methods that scientific investigations can follow.

a) What do you think? Is there one scientific method or set of steps that all investigations must follow to be considered science? Circle one answer:

- Yes, there is one scientific method (set of steps) to science.

- No, there is more than one scientific method to science.

If you answered "yes," go to (b) below.

If you answered "no," go to (c) below.

b) If you think there is one scientific method, what are the steps of this method?

c) If you think that scientific investigations can follow more than one method, describe two investigations that follow different methods. Explain how the methods differ and how they can still be considered scientific.

6. a) If several scientists, working independently, ask the same question (for example, they all want to find out what Oregon looked like 10,000 years ago, or what the structure of a certain protein is), will they necessarily come to the same conclusions? Explain why or why not.

b) Does your response to (a) change if the scientists are working together? Explain.

Appendix 2: Socioscientific Issues (SSIs) Questionnaire

1.Teachers understandings about Socioscientific issues

1.1 Is genetics a topic with socio scientific issues that can be experimented in science or not? Explain your answer.

1.2 Give examples of SSIs embedded in genetics.

1.3 How do learners handle such issues in the classrooms? 
1.4 How do you handle any differences of opinion between what learners bring to the classroom regarding issues on genetics?

1.5 Do you think teaching the topics genetics in South African Life Sciences considers learners' diverse/multiplicity of contextual knowledge. Explain your answer.

1.6 Why is it important in South African schools to cater for diverse contextual knowledge in schools?

1.7 As a teacher, how would you teach the topic DNA replication to your learners?

1.8 Which effective teaching strategies would you recommend in developing content continuity from grade $10-12$ when teaching genetics?

\section{Teaching SSIs using scientific inquiry approaches}

2.1 Do you think learners' environment influences the content and material that can be taught in genetics? Give a reasons.

2.2 Do you think teaching the topic genetics in South African Life Sciences considers learners diverse/multiplicity of context? Explain your answer.

2.3 Do you believe it is important to spend instructional time in your science classroom to teach learners about SSIs? Give reasons.

2.4 If you think it is important what do you think is the best way to teach SSIs embedded in the topic genetics? Give examples of approaches.

2.5 There is an albino child in your Life Sciences class, how would you approach the concept of albinism in that class?

2.6 Do you think the affected learner (learner with albinism) will take offence? If so how can you minimise the discomfort of the learner(s)?

\section{Genetic Engineering: Think of the pros and cons}

GMO foods are genetically modified organisms that have had new genes from other organisms added to their existing genes. Common genetic modifications include: adding antibacterial genes to plants, introducing genes that make the organism bigger or stronger, making new foods by adding genes from existing foods, and adding animal genes to plants and vice versa.

Some researchers claim that GMO foods' benefits are better food quality, taste, and disease -resistant crops so that we have higher yields and more efficient production. GMO's allow farmer to skip steps in the production process, like spraying herbicides and pesticides, because the crops are already resistant. In some crops, they claim the foods are modified to contain additional vitamins and minerals.

Another group of researchers claim that there has not been enough testing of GMOs and no real long-term testing to detect possible problems. Another problem is allergic reactions; genetic modification often mixes or adds proteins that were not indigenous to the original plant, causing new allergic reactions to the human body. Another risk is that the modified genes may escape into the environment.

3.1 How would you explain to the learners the differences in the claims made by the two groups of researchers?

3.2 One teacher decided to task learners to record the views of their community members about the GMOs and compile a report. Is this a scientific inquiry? Explain your answer.

3.3 Do you think that the strategy recommended above is applicable in South African context? Explain your answer.

3.4 Is it important to discuss ethical issues associated with the process of genetic engineering with the learners? Explain your answer.

3.5 If learners bring in their conflicting views to the classroom, would you consider discussion and analysis of those views as scientific inquiry? Explain your answer. 